\title{
Katalog uszkodzeń i usterek systemów i układów na tle architektury pojazdu
}

\begin{abstract}
Przedmiotem artykulu jest przedstawienie typowych, najczęściej pojawiajacych się uszkodzeń i usterek systemów, układów, zespołów i podzespołów na tle architektury trakcyjnego pojazdu szynowego. Jako reprezentatywny kolejowy pojazd trakcyjny, $z$ punktu widzenia tematu artykutu, przyjęto pojazd skupiajacy $w$ sobie maksymalna liczbe urzadzeń decydujacych o parametrach ruchowych, bezpieczeństwie jazdy, komforcie pracy obstugi, wygodzie pasażerów i ochronie środowiska.
\end{abstract}

\section{Architektura reprezentatywnego pojazdu trak- cyjnego}

Przedmiotem artykułu jest przedstawienie typowych, najczęściej pojawiających się uszkodzeń i usterek systemów, układów, zespołów i podzespołów kolejowego pojazdu trakcyjnego na tle jego architektury.

Jako reprezentatywny kolejowy pojazd trakcyjny, z punktu widzenia tematu artykułu, przyjęty został pojazd skupiający w sobie maksymalną liczbę urządzeń decydujących o parametrach ruchowych, bezpieczeństwie jazdy, komforcie pracy obsługi, wygodzie pasażerów i ochronie środowiska. Takim pojazdem może być zespół trakcyjny, $\mathrm{z}$ uwzględnieniem różnic wynikających z układu zasilania:

- z sieci trakcyjnej, czyli z układu zewnętrznego w elektrycznym zespole trakcyjnym

- z agregatu silnik spalinowy - prądnica główna, czyli z układu wewnętrznego) w spalinowym zespole trakcyjnym.

Zawieraja one bowiem wszystkie te podzespoły (za wyjątkiem aparatu pociaggowego), choć w mniejszej skali, które zabudowane są na lokomotywie, a zawierają za to podzespoły nie występujące na lokomotywie, służące do szeroko rozumianej obsługi podróżnych. Dla rozpatrywanego zagadnienia skala urządzeń nie ma istotnego znaczenia, bowiem struktura i funkcje elementów systemu diagnostycznego mogą być niezależne od mocy i gabarytów chronionych tym układem urządzeń.

Dla takiego pojazdu można wyróżnić co najmniej kilka obszarów konstrukcyjnych istotnych z punktu widzenia systematyki uszkodzeń. Przyjęto do analizy konstrukcję nowoczesnego pojazdu trakcyjnego, wyposażonego $\mathrm{w}$ nowoczesne systemy biegowe, hamulcowe $\mathrm{i}$ wyposażenie energoelektroniczne, jednak ograniczono rozważania do pojazdu zasilanego prądem stałym, co wynika $z$ realiów na PKP PLK, a co pozwoli wyeliminować z rozważań niektóre urządzenia, takie jak transformator i prostownik WN.

Przyjąć można schemat architektury całego pojazdu trakcyjnego przedstawiony na rys. 1 .
Prawie wszystkie wymienione w powyższym zestawieniu systemy, układy i urządzenia $\mathrm{w}$ swojej konstrukcji posiadają bardziej lub mniej rozbudowane nowoczesne sterowniki mikroprocesorowe, umożliwiające przystosowanie ich modułów wyjściowych do współpracy z układem sterowania i diagnostyki na poziomie pojazdu.

Wszystkie wchodzące w skład pokazanego schematu systemy i urządzenia mogą ulegać uszkodzeniom podstawowo $\mathrm{z}$ trzech powodów:

- normalnego zużycia eksploatacyjnego, łatwego do prognozowania i przeciwdziałania jego skutkom

- wad konstrukcyjnych i materiałowych, które objawiają się w różnym okresie eksploatacji

- niewłaściwej eksploatacji, tj. stosowanie niezgodnych z instrukcjami części zamiennych, materiałów eksploatacyjnych, niewłaściwych narzędzi do napraw, naprawy w technologii niezgodnej z instrukcją obsługi itp.

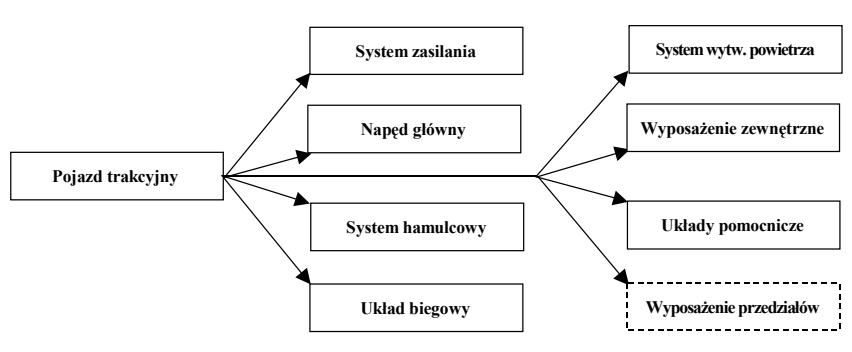

Rys. 1. Schemat architektury pojazdu trakcyjnego

W dalszej części opracowania zostaną poddane analizie dwie pierwsze przyczyny awarii i usterek.

W nowoczesnych pojazdach szynowych coraz częściej systemy diagnostyczne przekazują obsłudze, zarówno maszyniście jak i serwisowi warsztatowe$\mathrm{mu}, \mathrm{z}$ reguły poprzez odpowiednio oprogramowany panel operatorski (pulpitowy lub zabudowany bezpośrednio na urządzeniu), informacje na temat stanu niektórych urządzeń,. Z reguły, w odniesieniu do tzw. 
układu człowiek - maszyna, informacje te dzielone są na trzy poziomy:

- poziom alarmowy: umownie czerwony, informujący o automatycznym wprowadzeniu ograniczenia, np. mocy lub prędkości pojazdu lub wymagający ingerencji maszynisty zgodnie $\mathrm{z}$ instrukcją obsługi pojazdu

- poziom ostrzegawczy: umownie żółty, informujący o zbliżającym się zagrożeniu lub o stanie awaryjnym dotyczącym urządzeń niższego poziomu ważności, co może wymagać specjalnej uwagi maszynisty podczas dalszej jazdy i jest sygnałem dla działań serwisowych

- poziom informujący: umownie neutralny, informujący np. o zbliżaniu się do końca okresu eksploatacyjnego istotnego elementu, np. filtra w układzie wentylacyjnym, oleju w układzie smarowania itp.

Należy podkreślić, że podstawowym sposobem zapewniającym poprawną eksploatację pojazdu $\mathrm{z}$ wysokim wskaźnikiem gotowości technicznej jest skrupulatne i zgodne $\mathrm{z}$ instrukcjami producentów przeprowadzanie prac według planu przeglądowonaprawczego ujętego $\mathrm{z}$ Dokumentacji Systemu Utrzymania każdego pojazdu.

\section{Katalog typowych usterek i uszkodzeń System zasilania}

Podstawowymi urządzeniami w elektrycznym systemie zasilania pojazdu trakcyjnego są: pantografy $i$ wyłączniki szybkie, natomiast w spalinowym prądnica główna.

Schemat architektury systemu zasilania pojazdu trakcyjnego przedstawia rys. 2.

\section{Odbierak pradu}

Elementem odbieraka zużywającym się podczas normalnej eksploatacji są nakładki stykowe. W najnowszej generacji pantografów nakładki stykowe wyposażone są w kanał powietrzny biegnący wzdłuż całej wkładki i jego rozszczelnienie w dowolnym miejscu generuje sygnał do układu diagnostycznego informujący o dojściu do wymiaru granicznego i konieczności wymiany nakładki.

Inne elementy konstrukcji pantografu pozostałe moga podlegać awariom wynikającym z przyśpieszonego zużycia (elementy mechaniczne, jak sprężyny, siłowniki, zawory) lub nadmiernego zanieczyszczenia układu powietrznego odbieraka.

Izolatory wsporcze z kolei narażone są na uszkodzenia wynikające $\mathrm{z}$ działanie sił zewnętrznych, prowadzące do wyłamań mocowania lub pęknięć izolatora, wpływających na pogorszenie własności dielektrycznych.

\section{Wytacznik szybki}

Nowoczesne wyłączniki główne (szybkie) budowane są zarówno w wersji ze stykami z napędem elektromechanicznym, jak i ze stykami umieszczonymi w

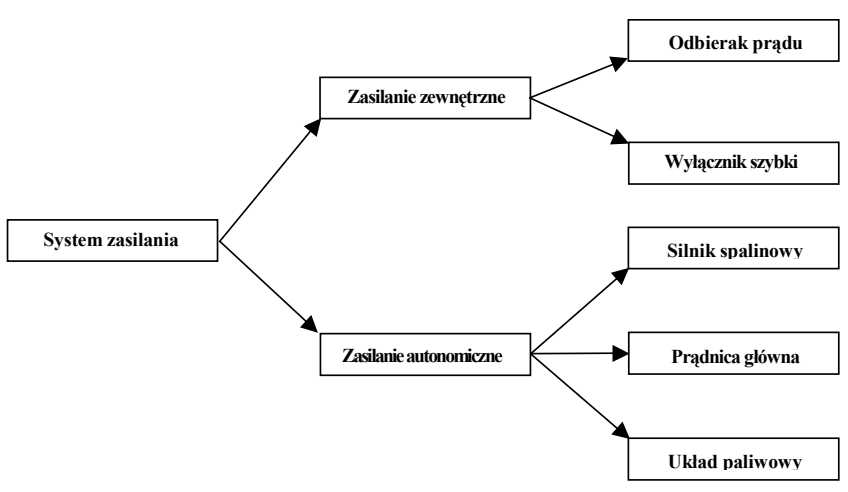

Rys. 2. Schemat architektury systemu zasilania pojazdu trakcyjnego

komorze próżniowej. Te drugie wyposażone sąjuż w wielofunkcyjne sterowniki mikroprocesorowe $\mathrm{z}$ funkcjami diagnostycznymi. Ocena stanu wyłącznika dotyczy zatem sprawności urządzeń towarzyszących, obecności napięcia sterowania, nadmiernej częstości łączeń w sytuacjach niesprawności urządzeń zasilanych przez ten wyłącznik. Ze względu na brak w tej konstrukcji elementów zużywających się, prognozowanie stanu wyłącznika nie jest priorytetowym zadaniem wewnętrznego układu diagnostyki wyłącznika.

W wersji z klasycznym układem styków mechanicznych diagnozowaniu może podlegać stan tych styków, zależny od liczby łączeń i wartości wyłączanych prądów. Istotnym ze względu na możliwość wystapienia usterki jest stan komory łukowej decydującej o prawidłowym przebiegu wyłączania prądów roboczych oraz, co istotniejsze, prądów zwarciowych, co wpływa z kolei na żywotność innych aparatów obwodu wysokiego napięcia.

Silnik spalinowy

Nowoczesny silnik spalinowy stosowany w lokomotywach lub tzw. power-pack w spalinowych zespołach trakcyjnych zawiera w sobie sterownik mikroprocesorowy z modułem prowadzącym pełną diagnostykę silnika, w tym rejestrację parametrów pracy i tzw. motogodzin. Ich konstrukcja jest na tyle dopracowana, że dotrzymywanie parametrów pracy (np. ograniczona liczba tzw. zimnych rozruchów) oraz wykonywanie prac przeglądowych zapewniają bezawaryjną pracę $\mathrm{w}$ deklarowanym przez producenta okresie.

Usterki obwodów sterowania, w opinii maszynistów, są trudniejsze do zlokalizowania niż usterki układów: pneumatycznego, wodnego i olejowego, a to $\mathrm{z}$ tego powodu, że te usterki można zlokalizować słuchowo i wzrokowo, a usterek układu elektrycznego nie da się zlokalizować ani wzrokowo ani słuchowo, zatem konieczne jest skorzystanie $\mathrm{z}$ narzędzi diagnostycznych.

Usterki tego zespołu, mogące wpływać na groźne awarie lub radykalne ograniczenie żywotności silnika, mogą dotyczyć:

- uszkodzenia układu wtryskowego; ze względu na tendencje podnoszenia ciśnienia paliwa 
wtryskiwanego do cylindrów paliwa pojawia się coraz więcej usterek dotyczących układu wtryskowego. Nie bez znaczenia jest tutaj również fakt, iż współpracujące ze sobą elementy są wykonywane z coraz większą dokładnością i nawet niewielkie zarysowanie powierzchni może unieruchomić wtryskiwacz i unieruchomić silnik. Typową usterką układu wtryskowego jest uszkodzenie pompy wtryskowej na skutek zużywania się współpracujących części.

- przegrzanie silnika; usterka może doprowadzić do uszkodzenia elementów uszczelniających pod głowica, a to prowadzi do remontu silnika. Do przegrzania może dojść na skutek niesprawnego układu chłodzenia w wyniku awarii wentylatora chłodnicy, bądź też wycieku płynu z nieszczelnego układu chłodzenia. Zagrożenie takie wzrasta szczególnie w upalne dni, zatem układy diagnostyczne powinny zwłaszcza w tym czasie nadzorować temperaturę silnika i w przypadku przekroczenia temperatury spowodować wygenerowanie sygnału ostrzegawczego lub wyłączającego silnik. Istotna dla tych celów jest ciągła sprawność czujników temperatury i ciśnienia, które są podstawą modułów diagnostycznych.

- niedogrzanie silnika; w okresie zimowym do prawidłowego rozruchu silnika, w celu zachowania jego deklarowanej żywotności, niezbędne jest uruchomienie układu podgrzewania czynnika chłodzącego. Diagnozowanie sprawności tego układu jest warunkiem koniecznym zapewnienia właściwej eksploatacji silnika.

\section{Uktad paliwowy ze zbiornikiem}

W układzie paliwowym najczęściej powtarzającą się usterką jest zanieczyszczenie pompy wtryskowej lub wtryskiwaczy.

\section{Pradnica główna}

W prądnicy głównej, ze względu na jej skomplikowaną budowę, może wystąpić szereg usterek lub awarii, zarówno w jej części mechanicznej (uszkodzenie łożyska, których liczba i konstrukcja zależy od sposobu jej połączenia z silnikiem spalinowym), owalizacja lub pogorszenie stanu powierzchni komutatora, pogorszenie warunków wentylacyjnych (zanieczyszczenie wlotu powietrza, uszkodzenie samego wentylatora).

Mogą pojawić się także niesprawności prądnicy w wyniku uszkodzeń w części elektrycznej prądnicy. Najczęstszym uszkodzeniem występującym w tym obszarze są uszkodzenia uzwojeń prądnicy, głównie przebicia lub zwarcia międzyzwojowe.
Monitorowanie stanu prądnicy odbywa się głównie poprzez kontrolowanie jej temperatury i jakości napięcia na jej zaciskach. Nowoczesne agregaty prądotwórcze stosowane w spalinowych pojazdach trakcyjnych wyposażone są w sterowniki mikroprocesorowe połączone z czujnikami i przetwornikami podstawowych parametrów prądnicy, zatem nie ma potrzeby budowania niezależnych modułów kontroli pracy prądnicy.

\section{System napędu glównego}

Podstawowymi urządzeniami w systemie elektrycznego napędu trakcyjnego pojazdu są: przekształtniki (napędu i hamowania), opornik hamulca elektrodynamicznego i silnik trakcyjny.

Schemat architektury systemu napędu pojazdu trakcyjnego przedstawia rys. 3 .

Przeksztaltnik trakcyjny (falownik i chopper hamulca elektrodynamicznego)

Energoelektroniczne urządzenia we współczesnych układach napędu elektrycznego pojazdów trakcyjnych są w głównej części odpowiedzialne za niezawodność i wykonywanie pracy przewozowej zgodnie $z$ rozkładem jazdy.

Praktycznie wszystkie wyposażone są w moduły kontroli pracy, realizujące tzw. autotesty po załączeniu układu, kontrolę sprawności czujników i przetworników pomiarowo-kontrolnych oraz stały monitoring pracy systemu napędowego. Występujące zakłócenia $\mathrm{w}$ pracy tych układów są spowodowane głównie usterkami ww. elementów kontrolnopomiarowych, uszkodzeniami elementów półprzewodnikowych, a czasami układów chłodzących zasilanych napięciem średnim lub zakłóceniami ich układów sterowania zasilanych napięciem niskim.

Sygnały o wszystkich stwierdzonych nieprawidłowościach są przekazywane do centralnego systemu sterowania i diagnostyki i wyświetlane na panelu operatorskim na pulpicie maszynisty.

Opornik hamowania ED

Oporniki hamowania elektrodynamicznego stanowią istotny element układu tego rodzaju hamulca. Dobierane są do mocy silników i parametrów choppera, który przetwarza do odpowiednich parametrów energię elektryczną powstała $\mathrm{w}$ procesie hamowania pojazdu. Ich dobrze opracowana konstrukcja $\mathrm{z}$ reguły nie jest powodem usterek uniemożliwiających poprawną pracę całego układu. Zdarzające się usterki, to $\mathrm{z}$ reguły awarie ich układu chłodzenia, np. brak napędu wentylatora. Tego typu awarie mogą być rozpoznawane prostymi elementami rozpoznającymi brak przepływu energii (przekaźniki prądowe) lub powietrza w kanale wwentylacyjnym i sygnalizowane w układzie diagnostycznym.

W przypadku ekstremalnych warunków atmosferycznych mogą się zdarzyć zanieczyszczenia izolatorów wsporczych (w przypadku mocowania nad żaluzjami wylotu powietrza do atmosfery w kierunku 
podtorza), prowadzące do przebicia izolacji i wyłączeń odpowiednio zabezpieczonego choppera.

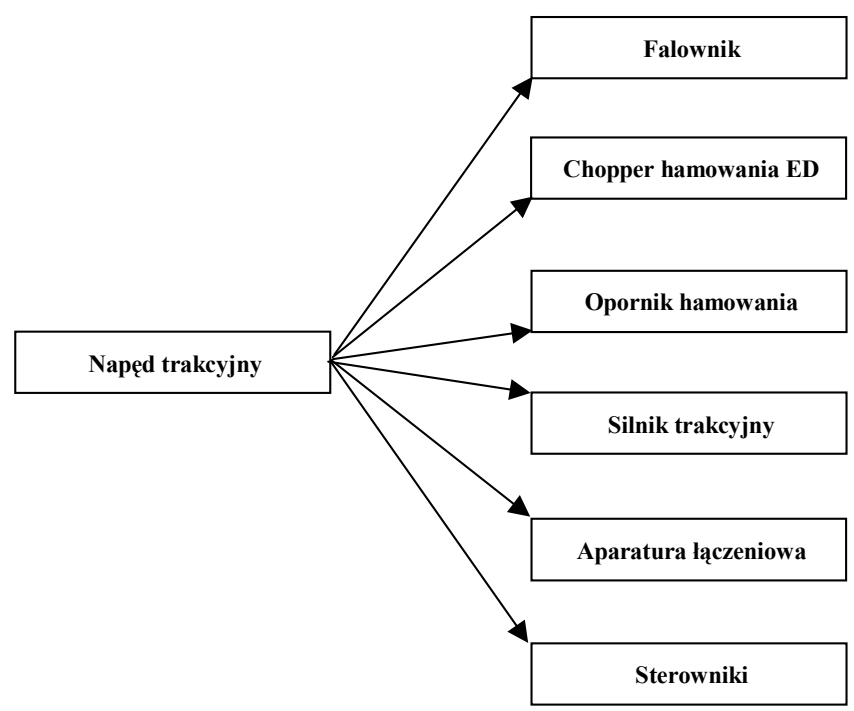

\section{Silnik trakcyjny}

Silniki trakcyjne stosowne w nowoczesnych pojazdach kolejowych w coraz większym stopniu są silnikami asynchronicznymi, praktycznie bezobsługowymi. Jedynymi podzespołami mogącymi ulec awarii są łożyska i zabudowane w silniku czujniki pomiarowo-kontrolne (prędkości obrotowej, temperatury). Sporadycznie mogą zdarzyć się uszkodzenia uzwojeń (przebicie izolacji, zwarcie międzyzwojowe). Stany takie wykrywane sa poprzez monitorowanie on-line parametrów wyjściowych falownika zasilającego silnik.

W przypadku nadal eksploatowanych silników prąu stałego $\mathrm{w}$ napędzie głównym do katalogu uszkodzeń dochodzą jeszcze następujące: niewłaściwa komutacja wynikająca ze złego stanu komutatora i szczotek, zawilgocenie uzwojeń, przebicia na szczotkotrzymaczach, przebicia izolacji i zwarcia międzyzwojowe twornika.

\section{Aparatura taczeniowa}

Istotnymi, ze względu na sprawność eksploatacyjną pojazdu, aparatami łączeniowymi, poza wymienionym już wcześniej wyłącznikiem głównym, są styczniki. W układach napędów elektrycznych nowej generacji zasilanych z przekształtników energoelektronicznych, ich rola w zasadzie ogranicza się do operacji bezprądowych. Służą głównie do zmiany konfiguracji układów, ładowania kondensatorów filtrów sieciowych itp., w związku z tym ich podatność na uszkodzenia jest znikoma, nie wymagaja monitorowania on-line i wystarczające $\mathrm{w}$ odniesieniu do nich jest skrupulatne przeprowadzanie prac zgodnie $\mathrm{z}$ cyklem przeglądowo-naprawczym.

\section{Sterowniki}

Sterowniki, zwłaszcza mikroprocesorowe wyposażone są w układy wewnętrznej autodiagnozy (autotesty). Sprawdzane są zwłaszcza warunki napięciowe, ciagłość torów pomiarowych czujników i przetworników oraz zgodność bitów w zainstalowanych programach.

\section{System hamulcowy}

Podstawowymi urządzeniami w systemie hamulcowym pojazdu są: układ sterowania hamulcem, urządzenia wykonawcze oraz zbiorniki powietrza. Dodatkowym elementem jest wcześniej opisany opornik hamowania ED.

Schemat architektury systemu hamulca pojazdu trakcyjnego przedstawia rys. 4.

\section{Uklad sterowania hamulcem}

Konstrukcja układów hamulcowych jest dopracowywana od początków rozwoju kolejnictwa. Wprowadzone systemy dublowania hamulców (sterowanie elektropneumatyczne hamulca powietrznego zastępowany jest samoczynnie sterowaniem pneumatycznym), dwuobwodowe kanały pneumatyczne hamulca zapewniają pełną redundancję w trakcie jazdy. Monitorowanie stanu hamulca zapewnione jest także poprzez układy rejestratorów pokładowych (tzw. haslerów) oraz przez kontrolę wzrokową przez maszynistę poziomu ciśnienia $\mathrm{w}$ przewodzie głównym i cylindrach hamulcowych [3].

$\mathrm{W}$ tej sytuacji diagnozowanie stanu układu sterowania odbywa się w dwóch trybach: serwisowym i rewizyjnym, przed rozpoczęciem jazdy.

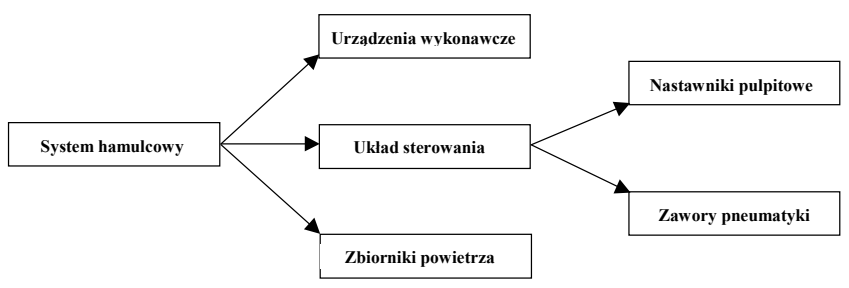

Rys. 4. Schemat architektury systemu hamulca pojazdu trakcyjnego

Sprawdzanie stanu w warunkach serwisowych odbywa się za pomocą wysokospecjalizowanej aparatury pomiarowo-kontrolnej.

Przed rozpoczęciem jazdy obowiązkowa jest próba hamulca wykonywana przez maszynistę lub w nowszych pojazdach trakcyjnych automatycznie przez system diagnostyczny. Sprawdzane są wtedy następujące funkcje: wdrażanie wybranych trybów hamulca oraz prawidłowość sygnałów z nastawników dla dwóch wariantów hamowania; hamulcem dodatkowym oraz zespolonym, a ponadto szczelność układu hamulcowego pociagu. 


\section{Urzadzenia wykonawcze}

Podstawowymi składnikami urządzeń wykonawczych hamulca zabudowanych w wózku, zatem pracujących w szczególnie trudnych warunkach (woda, kurz, śnieg, lód, twarde przedmioty z podtorza) są cylindry, klocki, tarcze, zaciski [4].

Ich usterki spowodowane czynnikami zewnętrznymi mogą być wychwycone podczas prac serwisowych lub przy próbach przed jazdą.

\section{Zbiorniki powietrza}

Zbiorniki sprężonego powietrza podlegają specjalnemu nadzorowi Urzędu Dozoru Technicznego i w związku z tym brak informacji z eksploatacji taboru o awariach zarówno zbiorników głównych jak i sterujących hamulca.

\section{Uktad biegowy i przeniesienia napedu}

Schemat architektury systemu układu biegowego pojazdu trakcyjnego przedstawia rys. 5 .

Rama wózka

Wózek jest jedną z najbardziej odpowiedzialnych za bezpieczeństwo systemu kolejowego konstrukcją pojazdu kolejowego.

Rama wózka przechodzi dokładne badania zmęczeniowe na stanowiskach badawczych, zatem jej przypadkowa usterka, bez przyczyn zewnętrznych, praktycznie nie wchodzi $\mathrm{w}$ rachubę. Potencjalne zagrożenie wystąpienia usterek/awarii związane jest z kluczowymi podzespołami wózka, dlatego dalsza analiza zostanie skoncentrowana na tych podzespołach.

\section{Przektadnia trakcyjna}

Elementami podatnymi na niesprawności i degradację są koła zębate i łożyska przekładni. Wykrycie nieprawidłowości jest możliwe poprzez analizę widmową drgań zmierzonych w łożyskach przekładni.

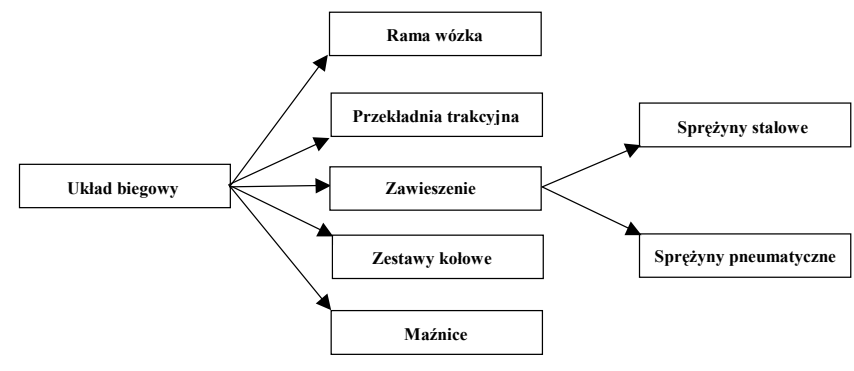

Rys. 5. Schemat architektury układu biegowego pojazdu trakcyjnego

\section{$\underline{\text { Łożyska maźnic }}$}

Pogorszenie stanu łożysk maźnic jest poważnym zagrożeniem dla bezpieczeństwa systemu kolejowego, zatem diagnozowanie tego węzła ma kluczowe znaczenie. Monitorowanie stanu łożysk zostało uznane jako podstawowy warunek bezpieczeństwa, dlatego uruchomiony został europejski program instalowania $\mathrm{w}$ torze systemów wykrywających podwyższoną temperaturę maźnic. tzw. HABD (hot axel box detection). Innym sposobem monitorowania stanu maźnicy stosowanym w lokomotywach jest wbudowywanie w korpus maźnic czujników temperatury [1].

Pomiar temperatury stosowany jest także do oceny łożysk w innych układach pojazdu: silnika trakcyjnego (o czym mowa w innym punkcie artykułu), przekładni trakcyjnej (np. w dużym kole zębatym) oraz w łożyskowaniu wału drążonego napędu trakcyjnego.

Zestawy kolowe

W zestawach kołowych może wystąić kilka groźnych stanów:

- niestabilność biegu w wyniku szczególnych warunków współpracy na styku koło - szyna. Nie jest to sensu stricte awaria, ale stan zagrożenia, możliwy do zlikwidowania odpowiednim, natychmiastowym przeciwdziałaniem. W pociagach wyższej klasy wymagany jest stały monitoring i na podstawie pomiaru przyśpieszenia mierzonego na ramie wózka oceniana jest stabilność biegu i w przypadku zagrożenia może być wdrażany układ obniżenia prędkości

- $\quad$ innym zagrożeniem mogącym doprowadzić do wykolejenia jest wzrost wartości poprzecznej siły prowadzącej na kole zestawu. Wartość jest w warunkach eksploatacyjnych trudna do rejestrowania, w związku z tym metodą zastępczą jest pomiar drgań zestawu kołowego.

- jednoznaczny defekt zestawu kołowego, czyli tzw. płaskie miejsce prowadzące do niestabilności biegu, uszkodzeń elementów wózka, degradacja toru. Skuteczną metodą monitorowania jest metoda pomiaru drgań na maźnicy zestawu kołowego.

- $\quad$ kolejnym defektem mogącym wywołać niepożądane skutki podobne do opisanych wyżej jest poligonizacja koła. Monitorowanie polega na pomiarze odchyłki bicia promieniowego, metodą pośrednią poprzez pomiar przyśpieszeń na korpusach lub łożyskach maźnic.

Zawieszenie spreżyste I i II stopnia

Zawieszenie sprężyste obu stopni wpływa zarówno na komfort jazdy, jak i na bezpieczeństwo pojazdu. Uszkodzenia w I stopniu usprężynowania przekłada się na zjawiska opisane przy wózku.

W II stopniu usprężynowania występują zarówno sprężyny stalowe (lokomotywy) jak i tzw. poduszki pneumatyczne (zespoły trakcyjne).

Uszkodzenia poduszek powietrznych polegaja głównie na ich rozszczelnieniu oraz na usterkach ich układu sterowania, którego zadaniem jest utrzymywanie stałej wysokości podłogi, niezależnie od obciążenia pasażerami. Ich konstrukcja zapewnia bezpieczne warunki jazdy nawet przy ich całkowitym opróżnieniu, lecz z ograniczoną przez układ sterowania lub maszynistę prędkością. 


\section{System wytwarzania sprężonego powietrza [2]}

Schemat architektury systemu wytwarzania i uzdatniania sprężonego powietrza w pojeździe trakcyjnym przedstawia rys. 6 .

\section{Spreżarka pomocnicza}

Sprężarka pantografów jest urządzeniem umożliwiającym uruchomienie elektrycznego pojazdu trakcyjnego. Jej prawidłowe działanie wymaga właściwych warunków zasilania jej silnika elektrycznego z baterii akumulatorów, co stwarza kłopoty szczególnie podczas bardzo niskich temperatur. Ponadto warunkiem niezawodnej pracy jest szczelność układu pneumatycznego, który zasila: pantografy oraz wyłącznik szybki i stycznik liniowy (jeśli ich napęd jest typu elektropneumatycznego). Możliwa jest tutaj diagnostyka otoczenia sprężarki, np. poprzez kontrolny, cyklicznie rejestrowany $\mathrm{w}$ fazie załączania pomiar narastania ciśnienia i ocena braku pogarszania parametrów jej układu.

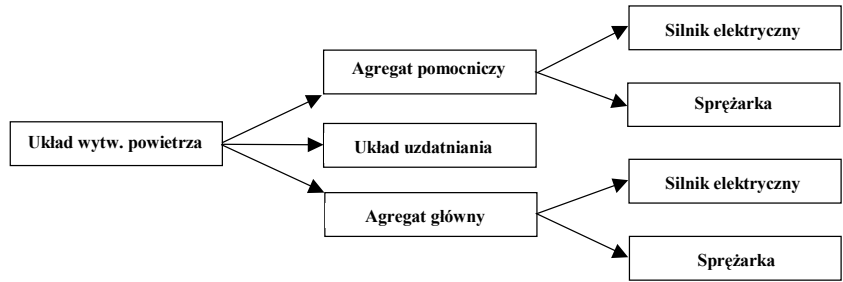

Rys. 6. Schemat architektury systemu wytwarzania i uzdatniania sprężonego powietrza

Sprężarka główna

Analizie zostały poddane nowoczesne sprężarki śrubowe, bowiem tłokowe są konsekwentnie zastępowane tymi pierwszymi. Podstawowymi wielkościami umożliwiającymi ocenę stanu sprężarki są: poziom oleju, temperatura oleju, temperatura powietrza na wylocie sprężarki, ciśnienie wylotowe sprężarki, ciśnienie przed i za filtrem powietrza, wilgotność względna powietrza za osuszaczem (poziom powyżej $80 \%$ generuje sygnał alarmowy). Na ich podstawie można wnioskować o ewentualnych uszkodzeniach. Dla celów diagnostycznych istotnym parametrem jest suma czasów pracy sprężarek, których znajomość umożliwia przeprowadzanie czynności przeglądowonaprawczych zgodnie z DTR sprężarki.

\section{Uktad uzdatniania sprężonego powietrza}

Ocena sprawności filtrów i osuszaczy odbywa się na podstawie zasad opisanych wyżej.

\section{Wyposażenie zewnętrzne pojazdu}

\section{Reflektory główne}

Reflektory główne są istotnym elementem bezpieczeństwa systemu kolejowego, nie tylko jako służące do oświetlania drogi kolejowej, lecz także jako składniki świateł obrysowych (tzw. sygnałowych) pojazdu, zatem przyczyny ich awarii powinny być dobrze rozpoznane, a same reflektory diagnozowane. Przyczyną niesprawności reflektorów są głównie same źródła światła (żarówki) lub ich układy zasilające. Monitorowanie stanu żarówek może odbywać się przez pomiar prądu, z pomocą przetworników i one mają wpływ na sprawność układu diagnozowania.

\section{Syreny i buczki ostrzegawcze}

Ze względu na specyfikę tych urządzeń (nadzór słuchowy maszynisty) nie ma powodu analizowania przyczyn ich ewentualnych usterek pod kątem metod ich diagnozowana.

Lampy sygnatowe (pozycyjne)

Wobec lamp sygnałowych będących częścią świateł obrysowych zastosowanie moga mieć te same metody jakie stosowane są przy reflektorach głównych.

\section{Elektryczne uktady pomocnicze}

Podstawowymi urządzeniami w systemie układów pomocniczych pojazdu są przetwornica statyczna (z reguły $\mathrm{z}$ kilkoma wyjściami napięcia), buforowo współpracująca $z$ nią bateria akumulatorów oraz zasilane z przetwornicy napędy pomocnicze.

Schemat architektury systemu układów pomocniczych pojazdu trakcyjnego przedstawia rys. 7.

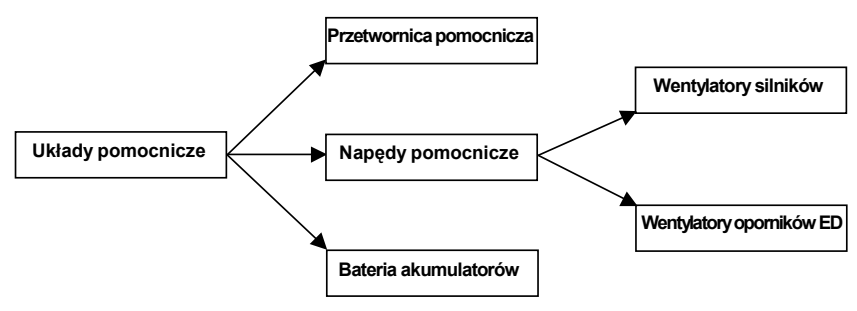

Rys. 7. Schemat architektury systemu układów pomocniczych

\section{Przetwornica pomocnicza}

We współczesnych pojazdach trakcyjnych przetwornice pomocnicze (kiedyś prądnice wirujące) zbudowane sa w podobnej technologii jak przekształtniki trakcyjne, zatem do przetwornic w zakresie ich usterkowości, mają zastosowanie te same uwagi co do przekształtników.

Wentylator silników trakcyjnych

$\mathrm{W}$ eksploatowanych pojazdach szynowych istnieja dwa rodzaje wentylacji silnika trakcyjnego:

- w układzie samoprzewietrzalnym (wentylator na osi silnika) - stosowany głównie w zespołach trakcyjnych, w których praktycznie nie występuje długotrwały okres pracy z małymi prędkościami obrotowymi silnika

- $\quad \mathrm{z}$ chłodzeniem zewnętrznym przez wentylator zabudowany wewnątrz lokomotywy tłoczący powietrze poprzez kanały wentylacyjne - stosowany głównie w lokomotywach, zwłaszcza manewrowych.

$\mathrm{W}$ związku $\mathrm{z}$ powyższym niesprawności tego układu mogą dotyczyć: 
- układu zasilania silnika wentylatora

- nieszczelności kanałów wentylacyjnych, zwłaszcza w obszarze przejścia między wózkiem a pudłem lokomotywy

- nieszczelności na kołnierzu wlotowym samego silnika

- poluzowania łopatek wirnika w silniku samoprzewietrzalnym.

Wentylator oporników

Prawidłowo skonstruowany i dobrany wentylator oporników w zasadzie nie podlega awariom. Jedynie sporadycznie zdarzające się $\mathrm{w}$ eksploatacji przypadki uszkodzeń dotyczą mocowania łopatek wentylatora, zwłaszcza w przypadku, gdy układ zasilania silnika wentylatora nie zapewnia odpowiednio łagodnego rozruchu. Inne przypadki niesprawności opisane zostały w systemie napędu głównego.

Bateria akumulatorów

W nowoczesnych pojazdach trakcyjnych stosowane są powszechnie akumulatory bezobsługowe, praktycznie nie ulegające awariom. Zdarzające się przypadki uszkodzeń dotyczą w zasadzie mechanicznego uszkodzenia płyt. Przypadki braku napięcia na zaciskach baterii akumulatorów spowodowane są w praktyce brakiem odpowiedniego ładowania ze źródła [5].

\section{Urzqdzenia wyposażenia przedziałów}

\section{Wentylatory kabiny}

To wyposażenie kabiny, ze względu na swoją lokalizację i stały nadzór maszynisty nie wymaga specjalnej ochrony za pomocą autodiagnostyki.

Klimatyzator kabinowy

Także to wyposażenie kabiny, ze względu na swoją lokalizację i stały nadzór maszynisty nie wymaga specjalnej ochrony za pomocą autodiagnostyki.

\section{Ogrzewacze przedziatów}

Wyposażenie wewnętrzne przedziałów pasażerskich jest praktycznie pod stałym nadzorem pasażerów, którzy w razie potrzeby zgłaszają niesprawność obsłudze pociagu. Nie ma ono wpływu na bezpieczeństwo kolei, zatem nie ma specjalnego powodów dla wyposażania takich układów w szczególnie rozbudowaną diagnostykę.

Klimatyzatory przedziałów pasażerskich

Do powszechnie już stosowanych klimatyzatorów przedziałów pasażerskich odnoszą się te same uwagi co do ogrzewaczy.

Oświetlenie przedziatów pasażerskich

Oświetlenie przedziałów pasażerskich jest także pod stałym nadzorem pasażerów, którzy w razie potrzeby zgłaszają niesprawność obsłudze pociagu. Także i ono nie ma wpływu na bezpieczeństwo kolei, zatem nie ma specjalnego powodów dla wyposażania takich układów w diagnostykę.

System drzwi zewnetrznych

Automatyczne drzwi zewnętrzne, ze względu na ich udział w bezpieczeństwie systemu kolejowego muszą podlegać specjalnemu nadzorowi. Zdarzające się usterki dotyczą głównie ich napędu, najczęściej elektropneumatycznego. Sterowniki tych napędów, produkowanych przez wyspecjalizowane firmy, potrafią rozróżnić stany awaryjne (niedomknięcie drzwi, brak otwarcia, brak blokady, itp.), zatem układy sterowania pojazdem nie muszą już diagnozować ich usterek, jedynie zgodnie z odpowiednim algorytmem odbierać sygnały ze sterowników drzwi.

\section{Podsumowanie}

Przedstawiony w niniejszym artykule katalog podstawowych usterek, które mogą pojawić się podczas pracy skomplikowanej maszyny, jaka jest pojazd kolejowy, szczególnie trakcyjny, zawiera tylko część możliwych do przewidzenia usterek i awarii. Skatalogowane zostały głównie te, które mogą znacząco wpływać na niezdolność pojazdu do kontynuowania pracy.

Rozszerzanie katalogu tych usterek będzie możliwe w wyniku realizacji dalszych prac rozwojowych, jakie są i będą prowadzone w Instytucie Pojazdów Szynowych „Tabor”.

Niniejsze artykuł powstał w wyniku realizacji projektu badawczego pt. Prognozowanie stanu technicznego glównych systemów pojazdu szynowego na podstawie analizy zmian wartości charakterystycznych parametrów podzespołów, finansowanego przez Ministerstwo Nauki i Szkolnictwa Wyższego (nr projektu N N509 336637).

\section{Literatura}

[1] Antkowiak T.: Diagnostyka i prognozowanie stanu węzła łożyskowego układu biegowego pojazdu szynowego. Pojazdy Szynowe nr 2/2012

[2] Goliwas D., Maluśkiewicz M.: Model systemu diagnostycznego urzqdzeń do wytwarzania i uzdatniania sprężonego powietrza pojazdach trakcyjnych. OR-10012. Opracowanie IPS ,,Tabor”. Poznań, 2011

[3] Kaluba M., Iwanowski J.: Uruchamianie laboratoryjnego modelu systemu diagnozowania hamulca dla lokomotywy. OR-10158. Opracowanie IPS „Tabor”. Poznań, 2011

[4] Kurpisz D., Durzyński A.: Opracowanie algorytmów obiektywnej oceny stanu aktualnego i prognozowanego zużcia klocków hamulcowych. OR-10042. Opracowanie IPS , Tabor”. Poznań, 2011

[5] Łastowski M.: Prognozowanie stanu pierwotnych $i$ wtórnych źródel energii elektrycznej. OR-9811. Opracowanie IPS ,,Tabor”. Poznań, 2010 